\title{
SOMATIC CHANGES OF UNIVERSITY STUDENTS IN BMI AND
}

WHR

\author{
Alena Cepková ${ }^{1}$, Olga Kyselovičová ${ }^{2}$, Oto Honz ${ }^{1}$, Marián Uváček ${ }^{1}$, Ján Žiška ${ }^{1}$ \\ ${ }^{1}$ Institute of languages and sport, The Faculty of Mechanical engineering, STU Bratislava, Slovakia \\ ${ }^{2}$ Department of Sport Educology and Sport Humanities, Faculty of Physical Education and Sport, \\ Comenius University in Bratislava, Slovakia
}

Summary: The article dealt with the assessment of somatic changes of the students at the Slovak University of Technology (STU), Faculty of Mechanical Engineering (FME), specifically expressed by Body Mass Index (BMI) and Waist Hip Ratio (WHR) during the years 2007 and 2013. In total 2228 men were involved in the study and measured upon their entry at the university. It was found out that the values of BMI belonged to the category of average range measured for adults (from $22.96 \mathrm{~kg} \cdot \mathrm{m}^{-2}$ to $\left.24.60 \mathrm{~kg} \cdot \mathrm{m}^{-2}\right)$ and indicates standard values. Statistically significant differences $(\mathrm{p}<0.01)$ were discovered between the years $2011\left(23.70 \mathrm{~kg} . \mathrm{m}^{-2}\right)$ and $2012\left(24.60 \mathrm{~kg} \cdot \mathrm{m}^{-2}\right), 2012\left(24.60 \mathrm{~kg} \cdot \mathrm{m}^{-2}\right)$ and $2013\left(22.96 \mathrm{~kg} \cdot \mathrm{m}^{-2}\right)$. In 2012 participants achieved in average the highest values $\left(\mathrm{BMI}=24.60 \mathrm{~kg} \cdot \mathrm{m}^{-2}\right)$, which borders with a moderate overweight. In the contrary, in 2013 the students achieved the lowest values of BMI (22.96 kg.m $\left.{ }^{-2}\right)$. A slight increase of average BMI values may be observed from the first test in 2007 until 2012. The predominance of standard weight was measured at $71 \%$ of the total number of monitored students and the predominance of overweight was measured at $22 \%$ of students from the total number of university students. The observation of WHR numbers makes us conclude that during our seven year study no significant differences were discovered in the first five years. The values were stable and from the mean point of view, they do not indicate the risk of development of diseases relating to overweight and obesity. In 2012 and 2013 a slight decrease of WHR values was detected $<0.85$. Statistically significant differences $(\mathrm{p}<0.05)$ were discovered between the years $2010(0.854)$ and 2011 (0.864), and also between 2011 (0.864) and 2012 (0.843). The lowest mean value of WHR was measured when performing the last test in the year 2013 (0.823). There was a statistically significant difference at $\mathrm{p}<0.05$ within the years 2012 and 2013. The highest mean value was discovered in 2011 (0.864). However, the average values achieved in a group of students were lower than 1.0, which can be evaluated as a set with no risk of obesity and overweight disease development.

Key words: BMI, WHR, somatometry, university students, overweight and obesity

DOI 10.1515/afepuc-2016-0003

(c) Acta Facultatis Educationis Physicae Universitatis Comenianae 


\section{Introduction}

University students at STU are predominately devoted to activities focused on their field of education with the purpose to master knowledge related to technical skills. Physical and sport training frequently provides them with the only space during their studies when their physical conditions can be developed. Thus, the purpose of physical education classes at the Faculty of mechanical engineering STU in Bratislava is that the students are taught to understand the meaning of a lifelong motoric activity as a key factor for balancing one's own physical and mental well-being. The assessment of physical development and competence of university students was also dealt with by authors such as Buková et al. (2008), Palovičová (2001), Kalinková and Šutka (2010). According to Strydom (2004), physical education creates a process which positively influences the development of student motoric abilities; however, the formation of positive attitude towards sport perceived as an inseparable part of lifestyle is also important. Strydom also points out that physical activities based on modern principles need to be implemented into the entire school system. Universities provide various possibilities for performing sport activities as specified by Duriček and Gallo (2007). Physical activities represent one of the basic cornerstones of human being and their study belongs to the field of scientific disciplines. One of universally accepted ideas nowadays is that physical movement and the appropriate sport activity has a positive influence on human health (Tjeerdsma-Blankenship and Solmon 2004). Stelzer (2005) emphasises the importance of physical exercise and a healthy lifestyle. Volker (2007) praises the influence of regular sport activities on health condition of adult people. Authors Katzmartzyk, Glendhill and Shephard (2001); Janssen and Katzmarzyk (2002) all confirm that absence of physical activities is projected into state economies and creates the burdening of social funds even in the most developed countries. The factor of economy thus influences also other fields of society. The lack of physical activities results into cardiovascular disease propagation, hypertension, diabetes, malignant form of tumours, osteoporosis, but also obesity and faulty body position (Britain, Donaldson 2004; Kratěnová et al. 2005).

Determination of BMI represents a fast and useful way to preliminary assessment of weight alteration, monitoring of obesity and a disease propagation risk. The boundaries of BMI values differ in various races. Asians, for instance, use slightly lower boundaries; obesity is diagnosed with people having higher BMI than 27.5 and the values within the interval $<18.5-23>$ are considered as ideal. The differences of fat accumulation in men and women are caused by their different hormone patterns. In case of women, fat accumulates in the area 
of breasts. This difference makes up 6 percent (Sharkey and Gaskill 2007). The amount of the rest of accumulated fat in both genders depend on such factors as, the lack of activities or on a calorific surplus that a person consumed, or on both factors simultaneously, which rapidly increases the quantity of fat in the body. In adolescence, when the quantity of ingested food is increased by excessive consumption, the most significant increase of fat cells occurs (Malina and Bouchard 1991). Our test was performed on students during the stage of their university studies, which is a period that from the human development point of view, falls into the category of adolescence (the age from 15 - 20 years) and early adulthood (age from $20-30$ years). From anthropomotoric point of view, Vobr (2013) assumes that the stage of adolescence is characterised by the end of human physical development and the start of fat accumulation. The differences between girls and boys are quite significant. Sharkey (1984) discovered that female university students have a dynamic lifestyle and the fat average value with these women was 18 to $22 \%$. Female sportsmen who were doing endurance type of sport had the fat average value 12 to $17 \%$. However, aging results into a $4 \%$ decrease of metabolic cell activity. These changes occur from the age of 25 . If a man does not reduce calorific consumption by the food alteration and the incorporation of sport exercises into his regime after 10 years upon completion of his university studies, he will start putting on weight considerably (Piers et al. 1998). In their research, Lee et al (2007) as well as Trudeau and Shepard (2005) discovered the relationship between a decrease of motoric activities of students and their increasing age.

A decrease of weight leads to improvement of physical, metabolic and endocrine problems, depression, anxiety, psychosomatic functioning, mood and the quality of life.

The objective of this article was to analyse and compare of somatic measurement of students at the Faculty of Mechanical Engineering from the year 2007 until the year 2013, special BMI and WHR.

\section{Method}

Groups of students were monitored and evaluated each year from 2007 until 2013 upon beginning of their first year of studies at STU in Bratislava. The total number of students participating during the period of seven years was 2228 . The number of students monitored per year is stated in the Table 1. 
Table 1

Number of students involved in the monitoring

\begin{tabular}{|l|c|c|c|c|c|c|c|}
\hline Year of the monitoring & $\mathbf{2 0 0 7}$ & $\mathbf{2 0 0 8}$ & $\mathbf{2 0 0 9}$ & $\mathbf{2 0 1 0}$ & $\mathbf{2 0 1 1}$ & $\mathbf{2 0 1 2}$ & $\mathbf{2 0 1 3}$ \\
\hline Number of students & 365 & 360 & 313 & 290 & 285 & 305 & 310 \\
\hline
\end{tabular}

The height was measured using a stadiometer with adjustable plate which is retracted to fit the head position of a tested participant. The weight was measured using decimal scales. A tested participant was weighed without shoes and the excessive clothing. The circumference of the selected body parts was performed using a measuring tape (Moravec 2002). The test was held at the beginning of the semester. Obtained results were used for the evaluation of WHR and BMI values of students.

BODY MASS INDEX (BMI) expresses the ratio of the body weight of tested person and the square value of his height. To identify persons whose fat is accumulated in the area of abdomen (visceral fat), the index WAIST TO HIP RATIO (WHR) is used. WHR assesses the ratio of waist circumference to hip circumference. An increased risk of disease occurs in a group of men whose value of WHR is above 1.0 and with women whose values are above 0.8. The obtained results were statistically evaluated and subdued a logical analysis. Evaluation was performed using the t-test. The values of statistical significance are following: $\mathrm{p}<0.10, \mathrm{p}<0.01, \mathrm{p}<0.05$. Statistical significance was evaluated only between two consecutive years.

\section{Results}

During seven years of monitoring it was discovered that in average the participants fell into the BMI international category of 'standard weight' defined for adults, with the BMI range from 22.96 to 24.60 . A statistically significant difference was observed in the year of $2011(23.70)$ and $2012(24.60)(p<0.01), 2012$ (24.60) and 2013 (22.96) $(\mathrm{p}<0.01)$. In 2012 (24.60) participants achieved the highest values of BMI (24.60) in average, which is a borderline case with the category of slight overweight (Fig.1). In 2013, the lowest average values of BMI were measured (22.96). In the group of subjects measured in 2013 it was higher $\%$ of students are underweight BMI $<18.50(7 \%)$ were measured as value in recent years (Tab. 2). We also found a smaller \% of students are overweight BMI 25.0 - 29.0 (17\%) than were in recent years (Tab. 2). Based on these data we can conclude the lowest BMI in 
2013. From the first measurement in 2007 until the year 2012 a slight increase of BMI may be observed.

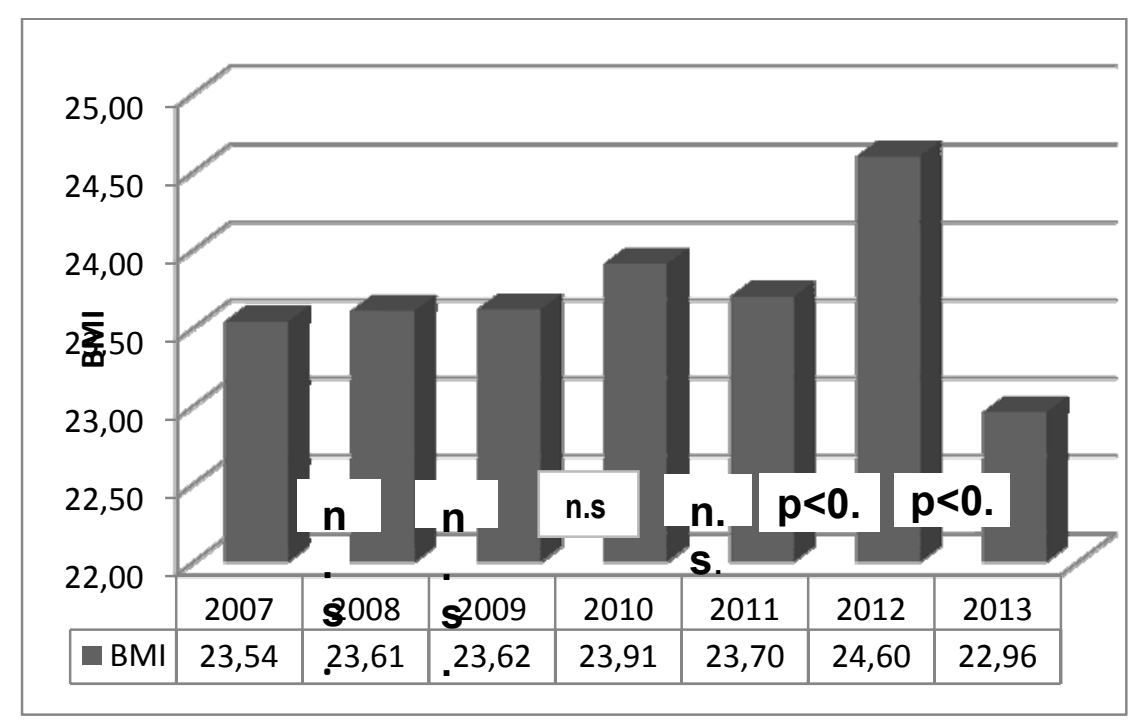

Figure 1

BMI development of students at the Faculty of Mechanical engineering (FME), STU Bratislava from years $2007-2013$

Simultaneously to our seven year monitoring of BMI values (2007 - 2013), values of WHR were also observed (Fig. 2). The highest average value was recorded in 2011 (0.864). In contrast to this, the lowest WHR value was observed during our last test in 2013 (0.823). From the year 2007 until the year 2010, recorded WHR values proved to be stable. A more significant decrease of WHR values was observed from 2011 until 2013. Statistically significant differences were discovered between the years 2011 (0.864) and 2012 (0.843) $(p<0.05)$ and also between the years $2012(0.843)$ and $2013(0.823)(p<0.05)$. We conclude that during seven years of our testing, no significant differences in average values were discovered in the first five years of our observation. WHR values in the range of 0.85 to 0.90 illustrate an even distribution of fat. This means that fat accumulates in the area of waist and hips, that is still within the norms of the standard figure definition. In years of 2012 and 2013 a slight decrease of WHR values was measured, WHR $<0.85$.

The accumulation of fat in the waist and hip area indicates the formation of the so called abdominal obesity, which represents the risk factor for development of serious chronical non-infectious diseases, such as cardiovascular diseases (ischemic heart disease, hypertension, vessel brain strokes, thromboembolic disease), metabolic diseases (metabolic syndrome, insulin resistance, glucose tolerance malfunction, diabetes mellitus of the second type, dyslipidaemia), respiration problems, oncologic and gynaecologic diseases, certain types 
of joint diseases, spine and muscle system (gonarthrosis, coxarthrosis) and certain types of dermatologic diseases (eczemas, mycosis, cellulite). Smoking and obesity are the most frequent causes of death. Obesity does not only cause the risk of health problems but also the feelings of physical and mental discomfort and social exclusion.

The average reached values of students at FME STU which were measured during seven years were lower than 1.0. We have detected that out of the total number of 2228 students monitored during the whole period, only 8 students whose WHR values equalled number 1 . Obtained average values indicate that our monitored group did not have problems resulting from overweight and obesity.

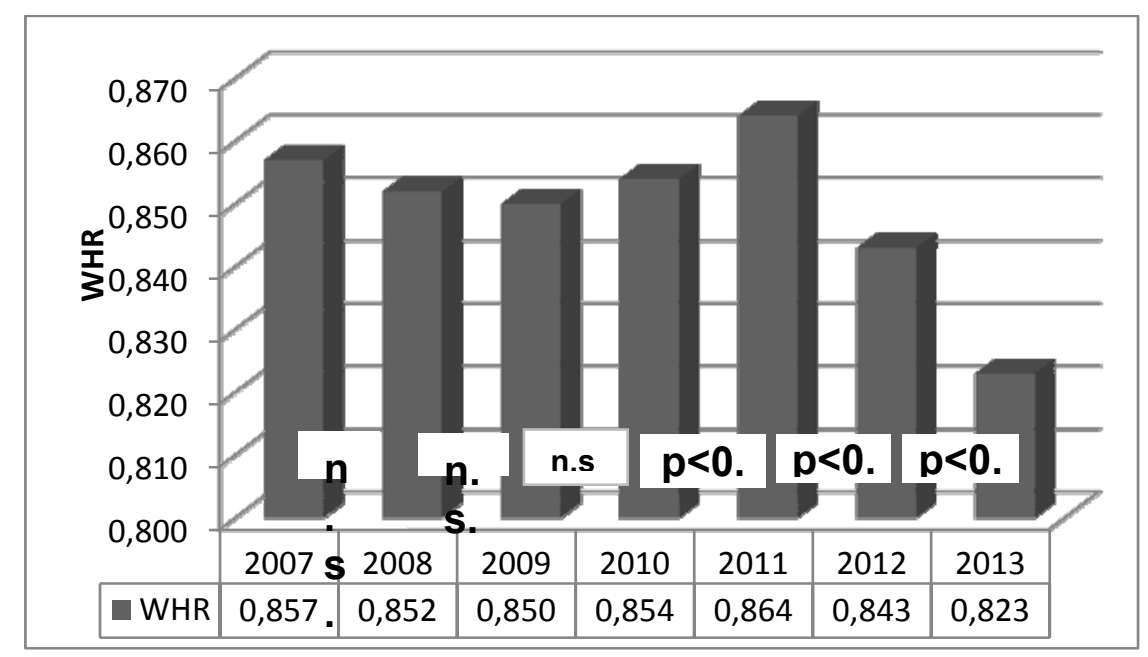

Figure 2

WHR development of FME students at STU, Bratislava from 2007 - 2013

Based on obtained BMI values the predominance to underweight, standard weight, overweight and obesity type I and type II calculated in each monitored year (Table 2) as well as in the whole monitored period. Tests revealed that the highest percentage of FME students at STU was represented by the BMI category 18.5 - 24.9. The standard weight was predominant with $71 \%$ out of the total number of FME STU students. This category is characterised by low health risk. In the BMI range $25.0-29.9$, overweight was predominant with $22 \%$ students out of total number of monitored FME STU students. This category is characterised by medium health risk. Obesity of the I. type was diagnosed in case of $4 \%$ students at $\mathrm{SjF}$ and obesity of the II. type was diagnosed with $1 \%$ of $\mathrm{SjF}$ STU students. These BMI categories indicate a high and extremely high risk of health diseases development. Contrarily to that, underweight was discovered with $2 \%$ of students. 
Table 2

Percentage distribution of BMI categories at FME STU

\begin{tabular}{|c|c|c|c|c|c|}
\hline & $\begin{array}{c}\text { BMI } \\
<\mathbf{1 8 . 5}\end{array}$ & $\begin{array}{c}\text { BMI } \\
\mathbf{1 8 . 5 - 2 4 . 9}\end{array}$ & $\begin{array}{c}\text { BMI } \\
\mathbf{2 5 . 0 - 2 9 . 9}\end{array}$ & $\begin{array}{c}\text { BMI } \\
\mathbf{3 0 . 0 - 3 4 . 9}\end{array}$ & $\begin{array}{c}\text { BMI } \\
\mathbf{3 5 . 0 - 3 9 . 9}\end{array}$ \\
\hline Year & Underweight & Standard weight & Overweight & $\begin{array}{c}\text { Obesity } \\
\text { type I }\end{array}$ & $\begin{array}{c}\text { Obesity } \\
\text { type II }\end{array}$ \\
\hline 2007 & $2 \%$ & $74 \%$ & $20 \%$ & $3 \%$ & $1 \%$ \\
\hline 2008 & $1 \%$ & $75 \%$ & $21 \%$ & $2 \%$ & $1 \%$ \\
\hline 2009 & $1 \%$ & $71 \%$ & $24 \%$ & $3 \%$ & $1 \%$ \\
\hline 2010 & $2 \%$ & $68 \%$ & $24 \%$ & $6 \%$ & $0 \%$ \\
\hline 2011 & $3 \%$ & $68 \%$ & $23 \%$ & $5 \%$ & $1 \%$ \\
\hline 2012 & $1 \%$ & $70 \%$ & $23 \%$ & $5 \%$ & $1 \%$ \\
\hline 2013 & $7 \%$ & $73 \%$ & $17 \%$ & $2 \%$ & $1 \%$ \\
\hline
\end{tabular}

\section{Discussion}

The comparison of BMI results achieved by our students with the stated results of university students found in other types of research, it can be concluded that no significant differences were observed. Hrčka et al. (2011) discovered that tested men reached average BMI values 25.75. The analysis of physical and functional profile of SJF STU students in Bratislava performed by Korček $(2003,2004)$ made him conclude that BMI values did not exceed the values of standard weight. Male sportsmen had in average higher BMI values than female sportsmen. Gádošiová (2003) confirmed the standard body mass at the University of Economy in Bratislava in case of $78 \%$ women and $79.7 \%$ men. In their long-term research Bobrík and Benko (2006) found out that STU students of the Faculty of Chemical engineering and food processing (FCHTP) in Bratislava belonged to the category of the standard weight. This wider observation makes us assume that university students in Slovakia belong to the category of standard body weight. People with this BMI value should try to maintain their weight by a balanced nutrition and the sufficient amount of motion. Health complications resulting from weight are less frequent in this category. Bartík et al. (2004) was monitoring BMI values of female students at the Faculty of Pedagogy PUMB in Banska Bystrica and discovered that they belonged to the category of standard weight; average reached values were from 20.8 to 21.2. Based on several results of Sailerová and Kopková (1997), we can conclude that BMI value rises with aging. Sailer and Kopková found out that in the age category of 20 to 29 year old women, only $2.7 \%$ of participants suffered from overweight. 
According to Dobiášová and Bučková (2013) a general mortality and mortality due to malignant tumours differs with genders. In case of men it is the BMI range $23-24.9$ and in case of women the BMI range is 19 - 22.9. As far as the WHR index is concerned, Hrčka et al. (2011) discovered higher WHR values in a non-sporting group as compared to a group of men and women performing certain kind of sport. The average WHR value achieved by students of physiotherapy was 0.878 . This value falls into a category that is without a risk of development of diseases related to overweight and obesity. According to Dukát et al. (2007) and his epidemiologic study IDEA, a high predominance of overweight and obesity was proven to be found with patients of Slovak GP doctors. GP doctors experience proved that an abdominal obesity made up $46.3 \%$ out of which a higher number was represented by women $(56.1 \%)$. Almost $38 \%$ patients that came to see their GP doctor suffered from obesity and every third woman was diagnosed with it (34.7\%).

According to a 2002 survey executed within the National program of health support focusing on the lifestyle of Slovak citizens and Romani minority, out of 4000 adult citizens, $44 \%$ of men were diagnosed with overweight, and $14 \%$ with obesity (Dobiášová a Bučková 2013). According to WHO, a higher predominance of overweight was discovered both in case of men and women (Body Mass Index (BMI) $\geq 25)$ as well as of obesity (BMI $\geq 30$ ) in case of older people ( 50 - 64 years) - unlike in the category of younger people ( 25 - 49 years). Overweight was more frequently discovered with men than with women, while obesity was more frequent with women from all Europe (Doak et al 2012). A fast rise of susceptibility to obesity during the last thirty years is mainly the result of cultural and environmental influences. Risk factors for development of obesity are mainly: highly calorific nutrition, too many helpings, low physical activities, sedentary lifestyle and irregular food consumption.

A longitudinal study of Sharkey and Gaskilla (2007) demonstrates that health risks of people with overweight and obesity were decreased by regular physical activity. The study has also confirmed that people with standard BMI who do not perform any sport have a higher risk of diseases than people with a high BMI but who are physically active. Trichopulou et al. (2001) confirmed that exercises represent an effective way of visceral fat metabolism, especially with men. It is well known that a physical activity contributes to prevention of obesity and of diseases related to it. This is proven by the study of Palovičová (2013) where positive changes of body weight, BMI and WHR were discovered in a group of secondary scholl students by means of aerobic program that lasted 8 weeks, for the period of 45 minutes, 3 times per week. Similar results were achieved by Izáková (2010). She confirmed that an exercise of kickbox aerobics causes a decrease of subcutaneous fat values, 
which made her recommend this type of activity as suitable for a group of young people. In the BMI categories standard, overweight and obesity which had a high WHR index, higher values of hypertension, diabetes and lipid problems were observed in contrast to other WHR values in the same BMI categories (Janssen, Katzmarzyk et al. 2002). Studies prove that physical activities protect people from health risk of obesity and in general increase human health.

\section{Conclusions}

From 2007 until 2013 students of the Faculty of Mechanical Engineering in average belonged to categories of standard weight (BMI values 18.50 to 24.99). The students we investigated their physical activity, eating habits before starting the study FME, we cannot justify the relevant changes in BMI between the straightening is performed years ago. The average WHR values of these students proved that during this period no significant change had occurred. The average values fluctuated below the value 1, which represents the category with no health risk. The values were stable and did not illustrate an increased occurrence of overweight or obesity, or the risk of cardiovascular or other types of diseases.

\section{References}

1. BARTÍK, P., Š. ADAMČÁK et al., 2004. Hodnotenie telesnej zdatnosti a pohybovej výkonnosti študentiek PF UMB v Banskej Bystrici. Banska Bystrica: UMB v Banskej Bystrici. ISBN 80-8083-029-0

2. BOBRÍK, M. \& L. BENKO, 2006. Vzt’ah medzi somatometrickými ukazovatel'mi a telesnou zdatnost'ou u poslucháčov FCHTP STU v rokoch 2003-2005. Pohyb a zdravie - 3. ročník. Trenčín: Trenčianska univerzita A. Dubčeka v Trenčíne, s. 31-38. ISBN 80-8075-138-2.

3. BUKOVÁ, A. et al., 2008. Pohybová aktivita študentov UPJŠ: Telesná výchova a šport, zdravie a pohyb. Zbornik referátov z 2. ročnika vedecko- pedagogickej konferencie učitel’ov TV. Prešov, , s. 132-136. ISBN 978-80-8045-515-6.

4. BRITAIN, G. \& L. J. DONALDSON, 2004. At least five a week: evidence on the impact of physical activity and its relationship to health. Department of Health.

5. DOAK, CM. et al., 2012. Age standardization in mapping adult overweight and obesity trends in the WHO European Region. Obes Rev 13(2):174-191. DOI: 10.1111/j.1467789X.2011.00943.x. Epub 2011 Nov 7. 
6. DOBIÁS̆OVÁ,V. \& L. BUČKOVÁ, 2013. Zdravý štýl života a nadhmotnost' a obezita. Kampaň „Odstráň obezitu“. (online) Publikované 16.10.2013. (Citované 30.9.2015). Dostupné zhttp://szstn.edupage.org/files/Obezita.pdf.

7. DUKÁT A., J. LIETAVA, B. KRAHULEC et al., 2007. Prevalencia abdominálnej obezity na Slovensku. Štúdia IDEA Slovakia. Vnitř Lék; 53 (4): 326-332.

8. ĎURÍČEK, M. \& M. GALLO, 2007. Trendy pohybovej rekreácie a súčasný životný štýl. Rožňava: Ústav vzdelávania, UPJŠ, ISBN 978-80-89168-20-0.

9. GÁDOŠIOVÁ, D., 2003. Stav telesnej zdatnosti študentov EU v Bratislave. Telesná výchova, šport, výskum na univerzitách. Bratislava: STU v Bratislave, s. 216, s. 66-70. ISBN 80-227-1972-2.

10. HRČKA, J., M. KOVÁŘOVÁ et al., 2011. Pohybová aktivita edukantov fyzioterapie vo vol'nom čase a jej reflexia na vybraných zdatnostných a zdravotných charakteristikách. Trnava: Univerzita sv. Cyrila a Metoda v Trnave. ISBN 978-80-8105-323-8.

11. IZÁKOVÁ, A., 2010. Vplyv kick box aerobiku na množstvo podkožného tuku u vysokoškoláčok. In: Pohybová aktivita v živote človeka: pohyb detí. Prešov: Prešovská univerzita, s. 168-172. ISBN 978-80-555-0301-1.

12. JANSSEN, I., P.KATZMARZYK et al., 2002. Body mass index, waist circumference, and health risk. Archives of Internal Medicine162: s. 2074-2079.

13. KALINKOVÁ,M. \& V. ŠUTKA, 2010. Závislost' somatických a motorických ukazovatel’ov vodného póla mužov SKP Košice. In:. Telesná výchova, šport a výskumu na univerzitách. 15. Medzinárodná vedecká konferencia. STU Bratislava. ISBN 978-80227-34035.

14. KATZMARZYK, P. T., N. GLEDHILL \& R. SHEPHARD, 2001. The economic burden of physical inactivity in Canada. Canadian Medical Association Journal, 163(11): 14351440.

15. KORČEK, V., 2004.Telesný a funkčný profil edukantov Strojníckej fakulty STU so zameraním na športové hry v akad.roku 2001/2002. In: Pohyb a zdravie. Physical Activities and Human Health. Vedecké práce. Trenčín: Trenčianska univerzita Alexandra Dubčeka v Trenčíne. ISBN 80-8075-014-9.

16. KORČEK, V., 2003. Telesný a funkčný profil edukantov 1. ročníka Strojníckej fakulty STU v akademickom roku 2000/2001. In: Optimalizácia zat’aženia v telesnej a športovej výchove. Load Optimation in Physical and Sports Education: Zborník referátov $\mathrm{z}$ vedeckého seminára. Bratislava: STU v Bratislave, s.79-83. ISBN 80-227-1874-2. 
17. KRATĚNOVÁ, J., K. ŽEJGLICOVÁ, M. MALÝ \& V. FILIPOVÁ, 2005. Výskyt vadného držení těla u dětí školního věku v ČR. Státní zdravotní ústav Praha, Centrum hygieny životního prostředí, Zdravotní ústav Středočeského kraje, pobočka Praha. Retrieved 20. 9. 2014 in World Wide Web:http://www.ftvs.cuni.cz/eknihy/sborniky/200511-16/prispevky/sdeleni/8-Kratenova.htm.

18. LEE, S. M., CH. R.BURGESON, J. E. FULTON \& CH. G. SPAIN, 2007. Physical education and physical activity: Results from theschool health policies and programs study 2006 - National Association for Sport and Physical Education (NASPE). Journal of School Health, 77/8:435-463.

19. MALINA, R. \& C. BOUCHARD, 1991. Growth, maturation, and physical activity. In: BOUCHARD, C. a i: Physical activity, fitness and health, Champaign, IL: Human Kinetics.

20. MORAVEC, R. et al., 2002. EUROFIT Telesný rozvoj a pohybová výkonnost'školskej populácie na Slovensku. Bratislava: SVSTVŠ, s. 180. ISBN 80-89075-11-8.

21. PALOVIČOVÁ, J., 2013. Program aerobiku ako prostriedok redukcie hmotnosti študentiek strednej školy. In: Zbornik vedeckých prác „Od výskumu k praxi v športe 2013“. Bratislava: STU Bratislava, s. 183-191. ISBN 978-80-227-4113-2.

22. PIERS, L., M. SOARES et al., 1998. Is the evidence for an age-related reduction in metabolic rate? Journal of Applied Physiology 85, s. 2196-2204.

23. SAILEROVÁ, E. \& E. KOPKOVÁ, 1997. Analýza testovania výsledkov žien mladšieho, stredného a staršieho veku. In Monitorovanie zdravotného stavu a pohybovej aktivity občanov SR. Bratislava: FTVŠ UK Bratislava, s. 12 - 16, 63. ISBN 80-967692-9-4.

24. SHARKEY, B. J., 1984. Training for cross-country ski racing. In: SHARKEY, B. J. and GASKILL, S. E., Fitness and Health. Champaign, IL: Human Kinetics.

25. SHARKEY, B. J. \& GASKILL, S. E., 2006. Sport physiology for coaches. In: SHARKEY, B. J. \& S. E. GASKILL. Fitness and Health. Champaign, IL: Human Kinetics.

26. SHARKEY, B. J. \& S. E. GASKILL, 2007. Fitness and Health. Champaign, IL: Human Kinetics.

27. STELZER, J., 2005. Promoting healthy lifestyles - prescription for physical educators. Journal of Physical Education, Recreation and Dance, Roč. 76, s. 26-29. ISSN 07303084.

28. STEPHENS, T., 1988. Physical activity and mental health in the United States and Canada: evidence of four popular surveys. Prev Med 17:35-47. 
29. STRYDOM, G. L., 2004. Physical aktivity, health and wellness: some challenges in the 21st century. African Journal for Physical, Health, Education, Recreation and Dance, 10, s. 220-229. ISSN 1117-4315.

30. TRICHOPOULOU, A., C. GNARDELLIS et al., 2001. Physical activity and energy intake selectively predict the waist-to-hip ratio in men but not in women. American Journal of Clinical Nutrition, 74: s. 574-578.

31. TRUDEAU, F. \& R. J.SHEPHARD, 2005. Contribution of school programmes to physical activity levels and attitudes in children and adults. Sports Med., 35/2: 89-105.

32. VOBR, R., 2013. Antropomotorika. Brno: Masarykova univerzita. ISBN 978-80-2106284-9.

33. VOLKER, K., 2007. Sport science and physical education trends and orientations. Sportunterricht, 56, s. 67-71. ISSN 0342-2402. 